\title{
Depositional Environment Reconstruction of OM-4 and OM-A Wells, Niger Delta, Nigeria, Using Palynomorphs and Wireline Logs
}

\author{
Taiwo O. M. , Okosun E. A., Goro A. I., Alkali Y. B. \\ Department of Geology, Federal University of Technology Minna, Niger State, Nigeria
}

Copyright $(2019$ by authors, all rights reserved. Authors agree that this article remains permanently open access under the terms of the Creative Commons Attribution License 4.0 International License

\begin{abstract}
Microfacies analysis combined with palynological studies were carried out on two wells (OM-4 and OM-A wells) in the Niger Delta to reconstruct the depositional environment of the penetrated wells from $8200-11350 \mathrm{ft}$ each in both wells. The succession studied yielded rich terrestrial components of the palynomorph assemblage, which gave zero to low PMI values in both wells, suggesting a paralic (freshwater to marginal marine) environment. Also, the abundance of mangrove swamp species such as, Zonocostites ramonae, Acrostichum aureum, Botryococcus braunii and Psilatricolporites crassus in both wells (which are brackish water indicators) denotes an environment of deposition with higher terrestrial influences and pockets of marine intrusions, confirming a paralic environment of deposition. The facies established from the wireline log signatures gave an alternating cylindrical to funnel shaped log motif with few units of bell shapes. This was interpreted as continental to marginal marine environment. The results of the facies analyses were correlated with the PMI values of the wells and generally cylindrical to funnel shaped facies were established with corresponding nil to low PMI values, confirming a paralic environment of deposition in both wells.
\end{abstract}

Keywords Palynological, Facie, Facie Association, Depositional Environment, Paralic, Niger Delta

\section{Introduction}

Palynological information from present day studies of modern organisms can be used to infer environmental conditions in the past and also predict future environmental conditions, since the distribution of organisms generally, are controlled by a combination of physical conditions of the surrounding area including terrain, vegetation structure, rainfall, sea level rise or fall and temperature. Information on the palynological assemblage is useful in reconstructing paleoenvironment because changes in the environment are reflected in palynologic assemblages [7,8]. Hence, palynomorphs are environment specific and their presence indicates the environment they represent.

Gamma ray log is used to predict varying lithology since its intensity depends on the mineralogy and shaliness of the sediments being measured. Sharp change in lithology suggests deposition break [1], hence abrupt change gamma ray $\log$ shapes indicates different environment of deposition.

To ascertain the depositional environment, there is need to carry out an environmental analysis which entails subdivisions of sedimentary successions on the basis of lithology, grain size, biogenic and physical sedimentary structures and stratification that contain direct relationship to the depositional processes that produced them. These processes result in various distributions of grain size (which can be inferred from the wireline logs) and biolologic properties that characterize the deposited sediment. This study focuses on the use of palynomorphs as the biologic component as well as the wireline logs (denoting physical properties of the sediments) in reconstructing the environment of deposition of the studied interval.

\section{Location and Geology of the Study Area}

The study area is located in the Western part of the Niger Delta which is situated in the gulf of Guinea on the West Coast of Central Africa. Niger Delta lies between Latitude $4^{\circ}$ and $6^{\circ} \mathrm{N}$ and Longitude $3^{\circ}$ and $9^{\circ} \mathrm{E}$, in the southern part of Nigeria. The studied wells, OM-4 and OM-A wells are located on the onshore portion of the Western Niger De1ta. They are located on latitude $4^{0} 40^{\prime} 28^{\prime \prime} \mathrm{N}$ and longitude $6^{0} 48^{\prime} 00^{\prime \prime} \mathrm{E}$ and $4^{0} 37^{\prime} 38^{\prime \prime} \mathrm{N}$ and $6^{0} 47^{\prime} 16^{\prime \prime} \mathrm{E}$ respectively as presented in Figure 1 fall within the coastal depobelt. The 
Niger Delta basin is bounded in the West by the Benin flank, in the East by Calabar flank in the south most part of Nigeria. It contains sediments of Paleogene to Holocene which were deposited in high energy deltaic environment. The sediments were laid in three lithostratigraphical order which are Benin Formation, Agbada Formation and Akata Formation.

The Akata Formation, which is composed of prodeltatic sediments, which are dominantly made up of under compacted marine shales and may contain patches of high pressured siltstone or fine grained sandstones. The age of the formation is between Eocene to Recent, but may be as old as Paleocene. Overlying the Akata formation is the Agbada Formation is composed of alternations of sand and shale sequences of delta-front, distributary channel and deltaic plain origin. The intercalated sequence of sandstones and shales of this formation has been shown by (Weher, 1971) to be a continuous cycles of marine and fluvial deposits. The topmost Benin Formation consists mainly of sandstones which are massive, highly porous and freshwater-bearing with thin shale interbeds distributed locally and are considered to be of braided-stream origin [2] The age of the formation varies from Oligocene (or earlier) to Recent.

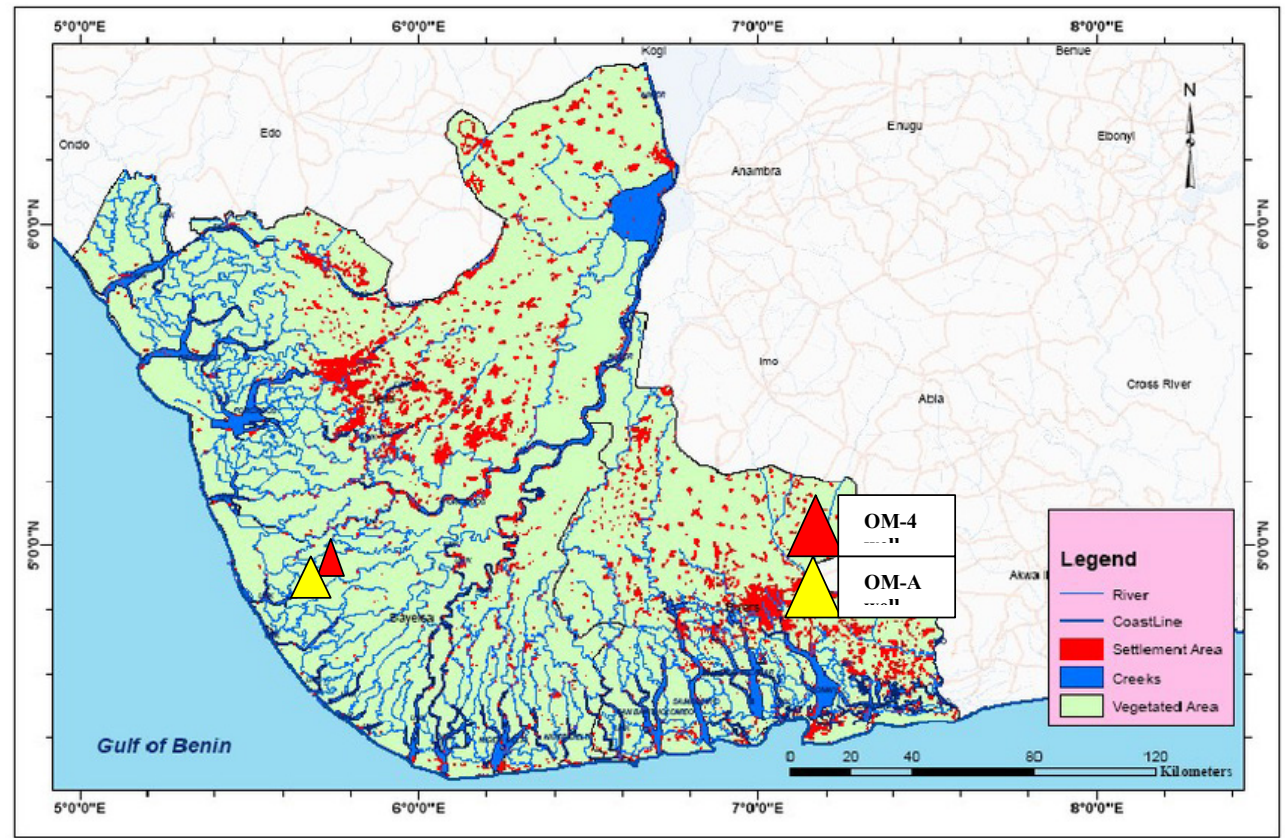

Figure 1. Niger Delta map showing location of wells (modified after ResearchGate) 


\section{Materials and Methods}

Ditch cutting samples and gamma ray logs for both wells were given by Chevron Nigeria Plc. The methodology involved two (2) processes which are; (i) palynological analysis and (ii) gamma ray logs interpretation.

For the palynomorphs to be used for depositional environment analysis, standard procedure for palynological preparation was followed which involved labelling and weighing of the samples, followed by the complete digestion of the samples in hydrochloric and hydrofluoric acid for the removal of carbonates and silicates respectively. The slides prepared were viewed using research binocular microscope. Identified species were noted, counted and recorded on the analysis sheet using the tally system and the results were inputted into the stratabug software to prepare the palynomorphs distribution chart. Environmental palynomorph specie indicators as well as the palynomorphs marine index (PMI) were used for the palynological interpretation of the depositional environment. The PMI index was proposed by [4] to interprete environments of deposition. PMI is calculated using the formula: $\mathrm{PMI}=(\mathrm{Rm} / \mathrm{Rt}+1) 100$, with $\mathrm{Rm}$ being the number of marine palynomorphs, which include dinoflagellates, acritarchs and foraminiferal test linings and Rt, the number of terrestrial palynomorphs (pollens and spores). In this study, Rm and Rt were expressed as the number of species per sample. High PMI values were interpreted to indicate normal marine depositional conditions, low values as brackish and nil values as fresh water [4]. This study adopts $0 \%$ as nil PMI values indicating freshwater, $1-50 \%$ as low PMI values indicating brackish and $51-100 \%$ as high PMI values indicating marine environment.

The gamma ray log used is the gamma ray log interpretation was achieved by establishing gamma ray signatures on the basis of the shapes produced by the logs. Lithofacies were interpreted based on gamma ray log models [3] shown in figure 2 .

\section{Result and Discussion}

The palynomorph distribution chart of OM-4 and OM-A wells shows a fair recovery of species count with fifty-one and forty-four species identified in both wells respectively. The recovered palynomorphs are shown on Table 1 and Table 2.



Figure 2. Gamma ray log model showing log motif and depositional environments (Cant, 1992) 
Table 1. Palynomorph distribution in OM-4 well onshore western Niger Delta

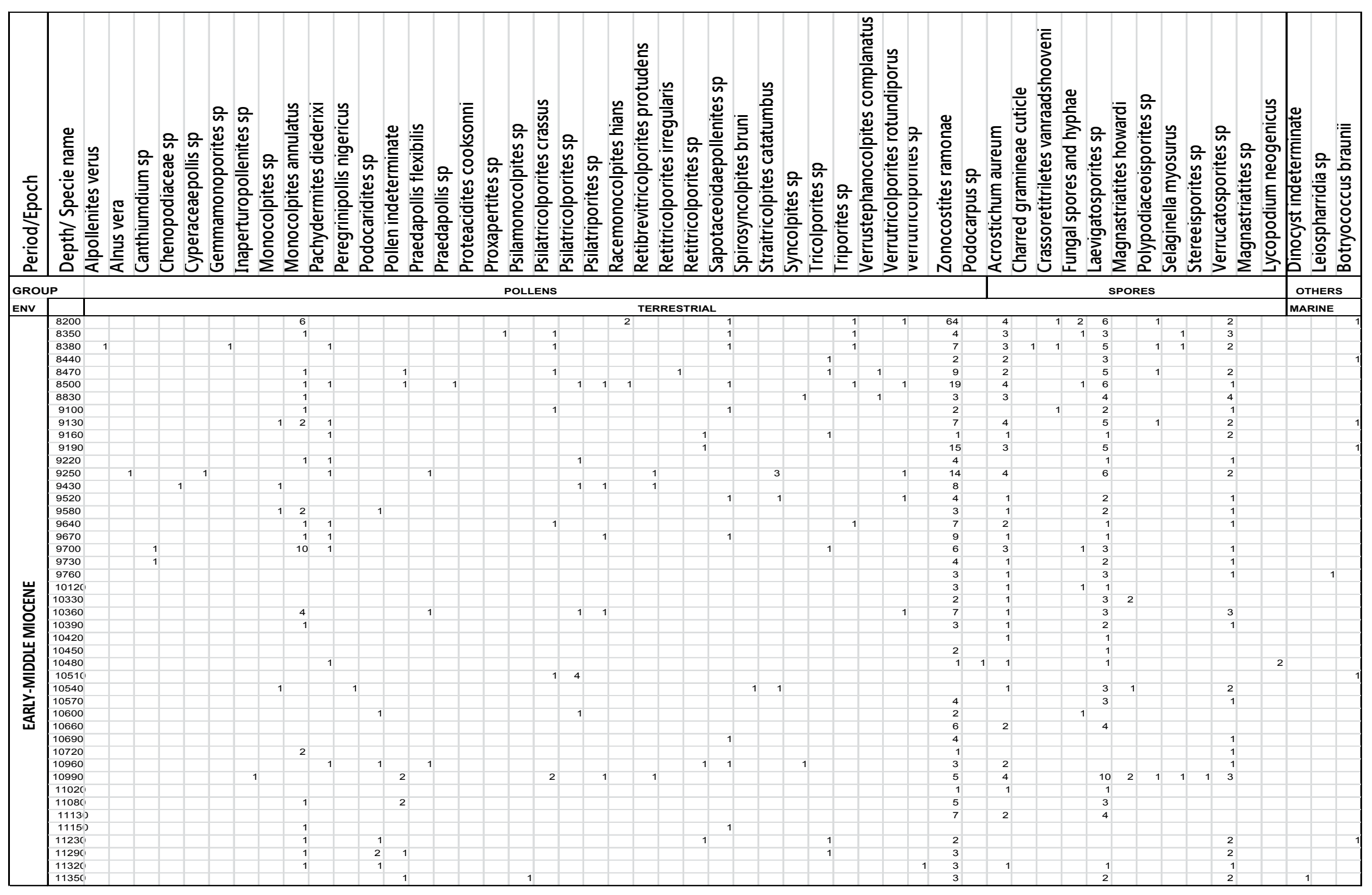


Table 2. Palynomorph distribution for OM-A well onshore western Niger Delta

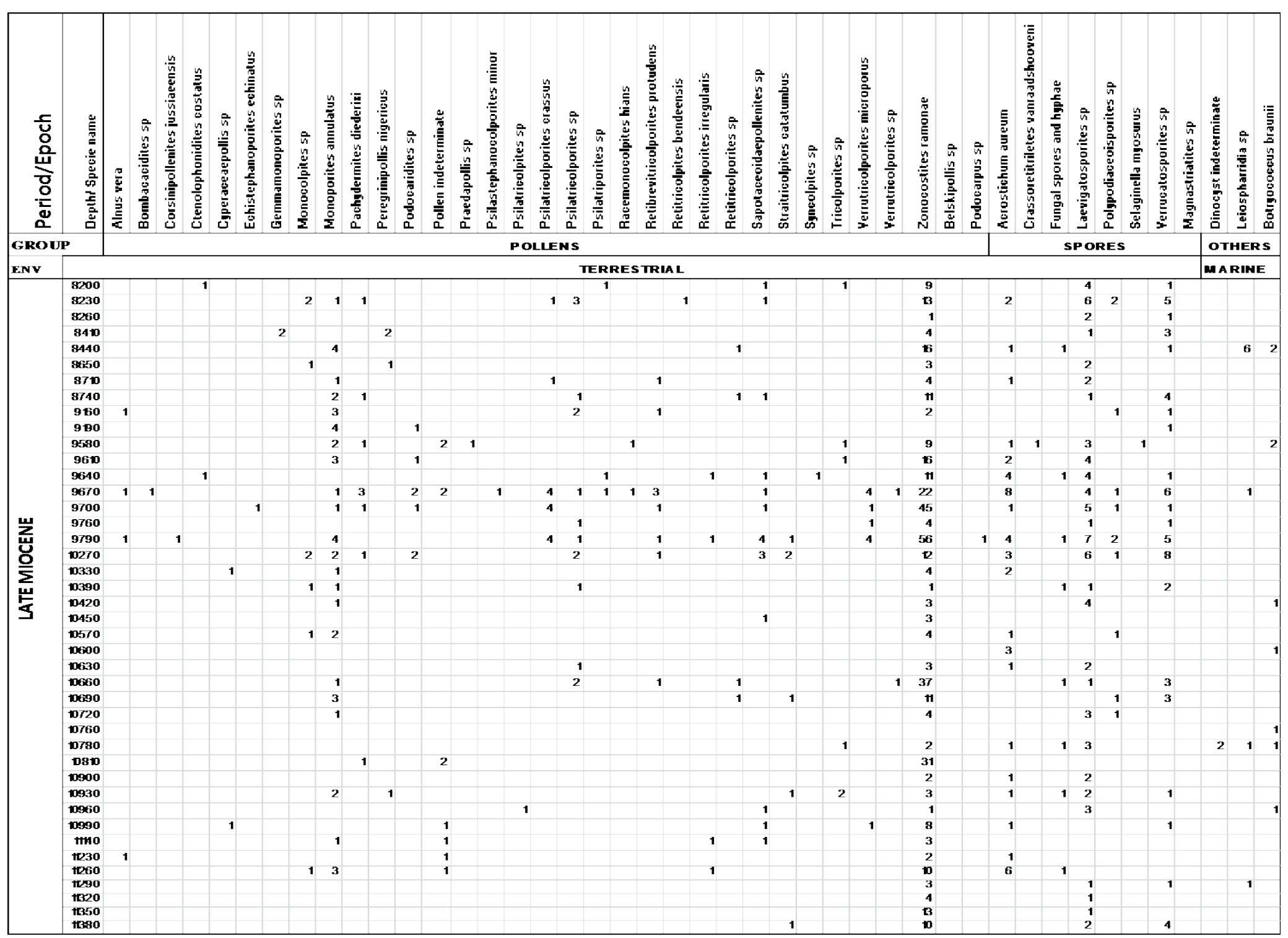


PMI values for OM-4 well were predominantly nil with most depth recording 0.0\% PMI values (Table 3). This indicates a fresh water environment. However, at depths of $9160 \mathrm{ft}, 9760 \mathrm{ft}, 10510 \mathrm{ft}, 10990 \mathrm{ft}, 11020 \mathrm{ft}, 11230 \mathrm{ft}$ and $11350 \mathrm{ft}$, low PMI values of $14.0 \%, 20 \%, 33.3 \%, 6.7 \%$, $25 \%, 12.5 \%$ and $16.7 \%$ were obtained respectively (Table 3; Figure 3). This suggests an environment of deposition characterized by mixed fresh and marine palynomorphs such as brackish environment. In OM-A well, most depths also had PMI values of $0.0 \%$, representing freshwater environment. Depths with low PMI values include $8440 \mathrm{ft}$ (14.3\%), 9160 - 9670ft (14.3\%), $10610 \mathrm{ft}(50 \%), 10810-$ $10780 \mathrm{ft}(10-50 \%), 10960 \mathrm{ft}(20 \%)$ and $11260 \mathrm{ft}(12.5 \%)$ as seen in Table 4, Figure 4. These depths indicate brackish water environment. From the PMI values, it is can be inferred that sediments were deposited in a paralic environment.

Table 3. PMI values for OM-4 well onshore Western Niger Delta

\begin{tabular}{|c|c|c|c|}
\hline Marine Diversity Rm & Terrestrial Diversity Rt & PMI $(\mathrm{Rm} / \mathrm{Rt}+1) \mathrm{X} 100$ & Depth \\
\hline 0 & 13 & 0 & 8200 \\
\hline 0 & 11 & 0 & 8350 \\
\hline 0 & 13 & 0 & 8380 \\
\hline 0 & 4 & 0 & 8440 \\
\hline 0 & 11 & 0 & 8470 \\
\hline 0 & 15 & 0 & 8500 \\
\hline 0 & 7 & 0 & 8830 \\
\hline 0 & 7 & 0 & 9100 \\
\hline 1 & 9 & 10 & 9130 \\
\hline 1 & 6 & 14.3 & 9160 \\
\hline 0 & 0 & 0 & 9190 \\
\hline 0 & 6 & 0 & 9220 \\
\hline 0 & 11 & 0 & 9250 \\
\hline 0 & 6 & 0 & 9430 \\
\hline 0 & 7 & 0 & 9520 \\
\hline 0 & 7 & 0 & 9590 \\
\hline 0 & 8 & 0 & 9640 \\
\hline 0 & 7 & 0 & 9670 \\
\hline 0 & 11 & 0 & 9700 \\
\hline 0 & 6 & 0 & 9730 \\
\hline 1 & 4 & 20 & 9760 \\
\hline 1 & 2 & 33.3 & 10510 \\
\hline 0 & 8 & 0 & 10540 \\
\hline 0 & 3 & 0 & 10570 \\
\hline 0 & 4 & 0 & 10600 \\
\hline 0 & 3 & 0 & 10660 \\
\hline 0 & 3 & 0 & 10690 \\
\hline 0 & 3 & 0 & 10720 \\
\hline 0 & 9 & 0 & 10960 \\
\hline 1 & 14 & 6.7 & 10990 \\
\hline 1 & 3 & 25 & 11020 \\
\hline 1 & 7 & 12.5 & 11230 \\
\hline 0 & 7 & 0 & 11290 \\
\hline 0 & 7 & 0 & 11320 \\
\hline 1 & 5 & 16.7 & 11350 \\
\hline
\end{tabular}




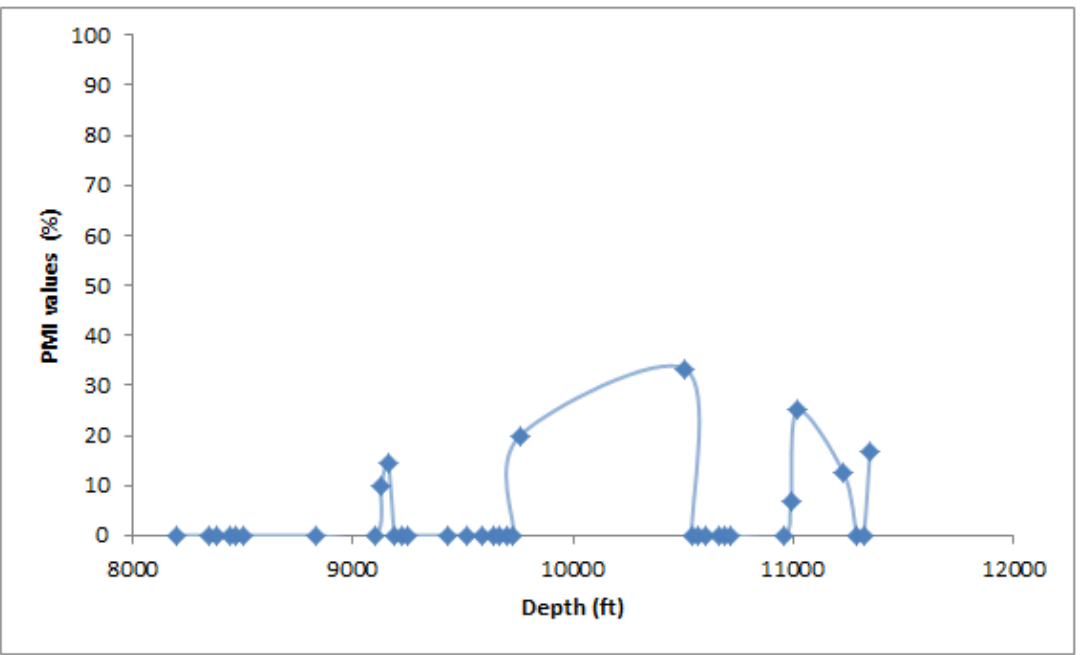

Figure 3. PMI Plot for OM-4 well onshore western Niger Delta



Figure 4. PMI plot for OM-A well onshore Western Niger Delta 
Table 4. PMI values for OM-A well onshore western Niger Delta

\begin{tabular}{|c|c|c|c|}
\hline Marine Diversity Rm & Terrestrial Diversity Rt & PMI $(\mathrm{Rm} / \mathrm{Rt}+1) \mathrm{X} 100$ & Depth \\
\hline 0 & 6 & 0 & 8200 \\
\hline 0 & 12 & 0 & 8230 \\
\hline 0 & 3 & 0 & 8260 \\
\hline 0 & 5 & 0 & 8410 \\
\hline 1 & 6 & 14.3 & 8440 \\
\hline 0 & 4 & 0 & 8650 \\
\hline 0 & 6 & 0 & 8710 \\
\hline 0 & 8 & 0 & 8740 \\
\hline 1 & 6 & 14.3 & 9160 \\
\hline 1 & 6 & 14.3 & 9190 \\
\hline 1 & 11 & 8.3 & 9580 \\
\hline 0 & 7 & 0 & 9610 \\
\hline 1 & 10 & 9.1 & 9640 \\
\hline 1 & 20 & 4.8 & 9670 \\
\hline 0 & 13 & 0 & 9700 \\
\hline 0 & 5 & 0 & 9760 \\
\hline 0 & 17 & 0 & 9790 \\
\hline 0 & 13 & 0 & 10270 \\
\hline 0 & 4 & 0 & 10330 \\
\hline 0 & 7 & 0 & 10390 \\
\hline 0 & 3 & 0 & 10450 \\
\hline 0 & 2 & 0 & 10480 \\
\hline 0 & 5 & 0 & 10570 \\
\hline 1 & 1 & 50 & 10600 \\
\hline 0 & 4 & 0 & 10630 \\
\hline 0 & 6 & 0 & 10690 \\
\hline 0 & 4 & 0 & 10720 \\
\hline 1 & 1 & 50 & 10780 \\
\hline 1 & 9 & 10 & 10810 \\
\hline 0 & 4 & 0 & 10900 \\
\hline 0 & 9 & 0 & 10930 \\
\hline 1 & 4 & 20 & 10960 \\
\hline 0 & 7 & 0 & 10990 \\
\hline 0 & 6 & 0 & 11140 \\
\hline 0 & 4 & 0 & 11230 \\
\hline 1 & 7 & 12.5 & 11260 \\
\hline 0 & 3 & 0 & 11290 \\
\hline 0 & 3 & 0 & 11320 \\
\hline 0 & 3 & 0 & 11350 \\
\hline 0 & 5 & 0 & 11380 \\
\hline
\end{tabular}




\subsection{Marker Species and Dominant Species Groups for Paleoenvironmental Studies}

Generally, the freshwater swamp species which include Laevigatosporites sp, Peregrinipollis nigericus, Racemonocolpites hians, Retitricolporites irregularis, Striatricolpites catatumbus, Crassoretitriletes vanraadshooveni and Magnastriates sp, were observed to be well represented in terms of diversity in both wells (Tables 2 and 3, Figures 5 and 6). These species were observed to occur at depths with $0.0 \%$ PMI values (although not restricted to only those depths), hence, confirming those depth intervals to have been deposited in a freshwater environment. Generally, of all the palynomorphs recovered from both wells (OM-4 and OM-A), Zonocostites ramonae was the most abundant species accounting for about $48 \%$ in OM- 4 well and 52\% in OM-A well, next to it is Laevigatosporites sp with about $19 \%$ in OM-4 well and 15\% in OM-A well, Acrostichum aureum 12\%, Verrucatosporites sp 7\%, Monoporites annulatus $5 \%$ and other palynomorphs accounting for about $9 \%$ in both wells respectively (Figures 5 and 6 ).



Figure 5. Percentage palynomorph species abundance in OM-4 well

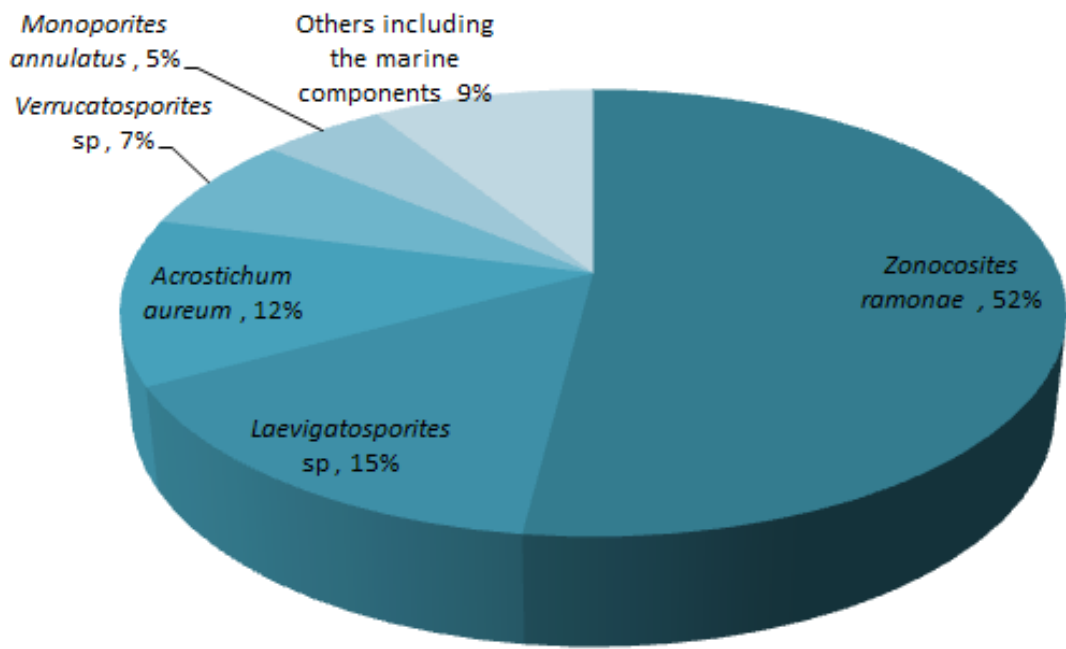

Figure 6. Percentage palynomorph species abundance in OM-A well 
In both wells, high percentages of mangrove species (brackish water indicators) which includes Zonocostites ramonae, Acrostichum aureum, Psilatricolporites crassus, Verrucatosporites sp and Botryococcus braunii $[5,6,10]$, were recorded (Figures $5 \& 6$ ). Also depth intervals with low PMI values showed an assemblage of at least two mangrove swamp species. For instance, in OM-A well, at $8440 \mathrm{ft}$ with PMI value of $14.3 \%$ (Table 4), Zonocostites ramonae, Acrostichum aureum, and Botryococcus braunii were present at that depth. Although, the presence of these species was not limited to the depths with low PMI values, their presence at such depths had higher population than the freshwater species. These mangrove species were generally most abundant in terms of population in both wells especially Zonocostites ramonae and Acrostichum aureum. The presence of these Mangrove swamp species further confirms that the depths with low PMI values were deposited in a brackish environment.

The major palynomorph groups that were used in the paleoenvironmental studies are pollen and spores, representing the terrestrial and dinocysts representing marine influences [9]. From Figures 5 and 6, it can be seen that pollen and spores accounted for $71 \%$ and $23 \%$ in
OM-4 well and $75 \%$ and $18 \%$ in OM-A well, compared to low counts of marine influences (dinoflagellates) which had $4 \%$ and $5 \%$ in OM-4 and OM-A wells respectively, it indicates an environment of deposition with greater terrestrial influences. This result indicates paralic environment of deposition with strong terrestrial influence. This character is common to fluvial-coastal environments.

From the PMI values, the dominant species group and presence of marker species, sediments within both wells were deposited in a paralic environment denoting a fluvial to coastal environment.

\subsection{Wireline Log Interpretation}

Gamma ray $\log$ was used to infer the possible depositional environment in the studied area by considering the shapes displayed by the log motif (that is; bell shape, funnel shape and cylindrical shape) which in turn determined the possible nature of sediments deposited (that is; fining upward, coarsening upward and blocky respectively). The summary of the inferred environments from log motif against depth in both wells are shown in Figures $7 \& 8$ below;

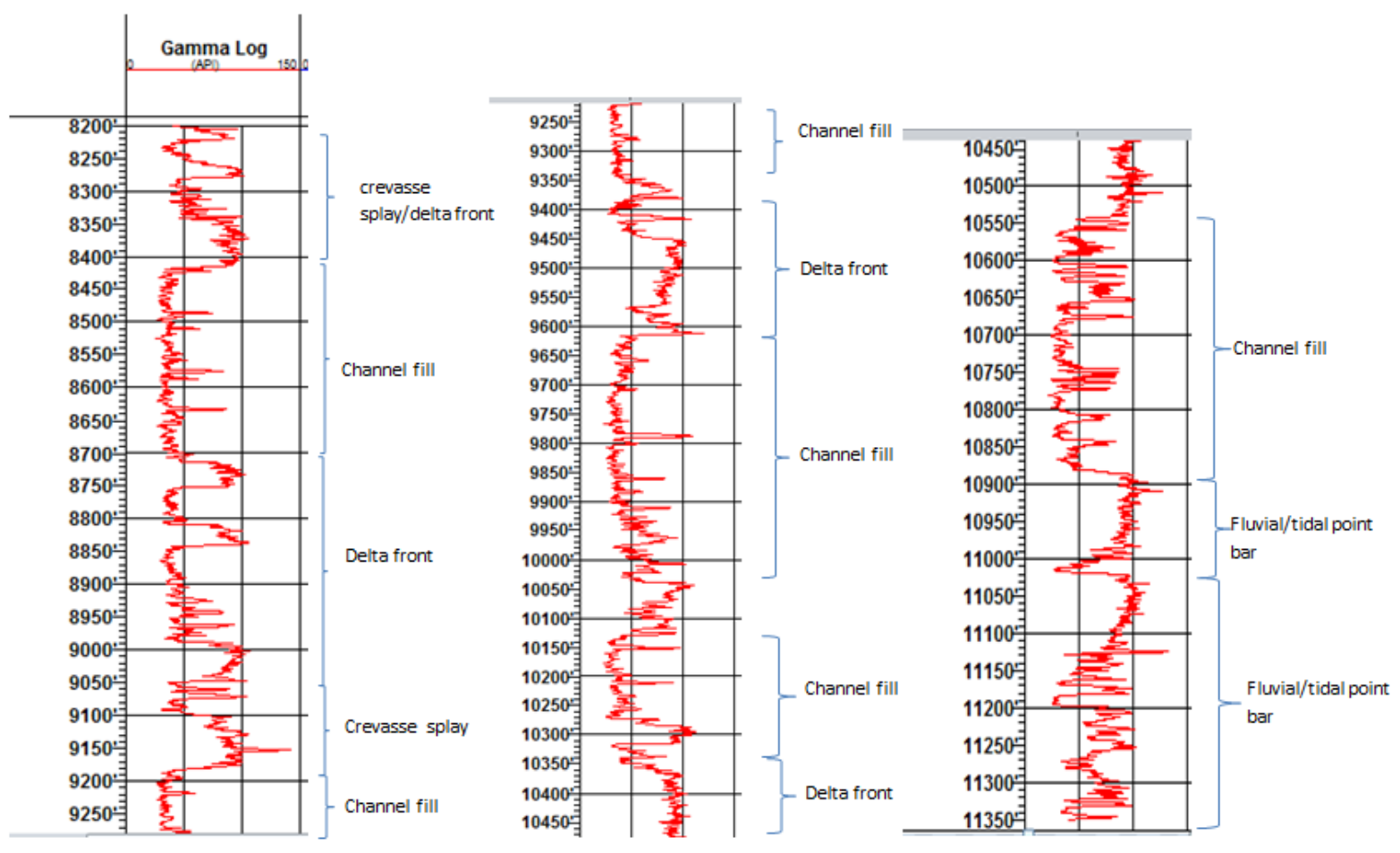

Figure 7. Gamma ray log of OM-4 well onshore western Niger Delta 



Figure 8. Gamma ray log of OM-A well onshore western Niger Delta

From the gamma ray log, it is observed that the OM-4 well was dominated by crevasse splay/delta front, channel fill and the fluvial point bar facies based on the dominance of cylindrical and funnel shaped log motifs which generally denote a transitional environment with greater fluvial influences. OM-A well on the other hand was dominated by delta front/prodelta facies with fewer channel fill facies. This is also based on the dominance of the funnel shape and fewer cylindrical $\log$ motifs. This also denotes a transitional environment with more marine influences. The PMI values in OM-A well were higher and occurred at more depths than those in OM-4 well, with two depths recording up to $50 \%$, marking the highest PMI values recorded in this study.

OM-4 well probably had more terrestrial influence because they are more proximal to the sea than OM-A well, which is relatively more distal (figure 1).

A correlation of the established facies from the log was done with the PMI values to establish concise depositional model in both wells. The F, C and B letters were used to represent the $\log$ motifs meaning funnel (coarsening upwards), cylindrical (blocky) and bell shapes (fining upwards) respectively. Tabular illustrations of these facies model established for the study are shown below in Tables $5 \& 6$;

\section{Conclusions}

Facies units were established from the gamma ray wireline $\log$ in both wells using the log motif after [3]models with OM-4 well, showing a transitional environment with higher terrestrial influences and OM-A well showing higher marine influences. PMI values were generated with dominantly nil PMI values recorded at most depths, and few depths having low PMI values. A correlation of the facie units established with the PMI values indicated a continental (Channel fill) to marginal marine (ranging from crevasse splays/delta front to prodelta) depositional environments.

Recovery of freshwater swamp species as well as abundance of mangrove species also confirms deposition in a paralic environment. 
Table 5. Depositional environments for OM-4 well onshore western Niger Delta

\begin{tabular}{cccc}
\hline Depth (ft) & PMI Value & Log Motif & Depositional Environment \\
\hline $8200-8400$ & Nil & F & Marginal marine (Crevasse splay/Delta front) \\
\hline $8400-8700$ & Nil & C & Continental (Channel fill) \\
\hline $8700-9050$ & Low & F & Marginal marine (Delta front) \\
\hline $9050-9200$ & Nil & F & Marginal marine (Delta front) \\
\hline $9200-9400$ & Nil & C & Continental (Channel fill) \\
\hline $9400-9620$ & Nil & F & Marginal marine (Delta front) \\
\hline $9620-10320$ & Low & C & Continental (Channel fill) \\
\hline $10320-10550$ & Low & F & Marginal marine (Delta front) \\
\hline $10550-10900$ & Nil & C & Continental (Channel fill) \\
\hline $10900-11350$ & Low & B & Continental (Fluvial/tidal point bar) \\
\hline
\end{tabular}

Table 6. Depositional environments for OM-A well onshore Western Niger Delta

\begin{tabular}{cccc}
\hline Depth (ft) & PMI Value & Log Motif & Depositional Environment \\
\hline $8200-8450$ & Low & F & Marginal marine (Delta front) \\
\hline $8450-8880$ & Nil & C & Continental (Channel fill) \\
\hline $8880-9700$ & Low & F & Marginal marine (Delta front) \\
\hline $9700-10450$ & Nil & C & Continental (Channel fill) \\
\hline $10450-10720$ & Low & F & Marginal marine (Delta front) \\
\hline $10720-11020$ & Low & C & Marginal marine (Prodelta) \\
\hline $11020-11350$ & Low & F & Marginal marine (Delta front) \\
\hline
\end{tabular}

\section{REFERENCES}

[1] Adeel, N., \& Sarfraz, H. S., (2016). Sedimentary facies interpretation of gamma ray log as basic well logs in Central and Lower Indus Basin of Pakistan. Geodesy and Geodynamics, 7(6), 432-443. [1]

[2] Avbovbo, A. A. (1978). Tertiary Lithostratigraphy of Niger Delta. American Association of Petroleum Geologist Bulletin, 62, 295-306. [2]

[3] Cant, D. J. (1992). Subsurface facies analysis. In: Walker, R. $\mathrm{G}$ and N.P. James (Eds.), Facies Models: Response to sea level change. Geological Association of Canada, St Johns Nfld, pp. 409. [3]

[4] Helenes, J., de-Guerra, C., \& Vásquez, J. (1998). Palynology and chronostratigraphy of the Upper Cretaceous in the subsurface of the Barinas area, western Venezuela. The American Association of Petroleum Geologists Bulletin, 82, 1308-1328. [4]

[5] Ige, O. E. (2009). A Late Tertiary Pollen record from Niger Delta, Nigeria. International Journal of Botany, 5, 203-215. [5]

[6] Ige, O. E. (2011). Vegetation and Climatic History of the Late Tertiary Niger Delta, Nigeria, based on Pollen record. Resources Journal Botany, 6, 21-30. [6]
[7] Ojo, O. J., \& Akande, S. O. (2004). Palynological and Palaeoenvironmental studies of Gombe Formation, Gongola Basin, Nigeria. Journal of Mining and Geology, 40, 143149. [7]

[8] Oloto, I. N. (1989). Maastrichtian dinoflagellate cyst assemblage from the Nkporo Shale on the Benin flank of the Niger Delta. Review of Palaeobotany and Palynology, 57, 173-186. [8]

[9] Soronnandi-Ononiwu, G. C., Omoboriowo, A. O., Yikarebogha, Y., \& Chiaghanam O. I. (2014). Palynology and Paleoenvironmental Study Of Akukwa-1 Well, Niger Delta and Anambra Basins, Nigeria. International Journal of Scientific and Technology Research 3(2), 297-304. [9]

[10] Sowunmi, M. A. (1981). Aspects of Late Quaternary vegetational changes in West Africa. Journal of Biogeography, 8, 457-474. [10] 